Copyright (C) 2020 University of Bucharest Printed in Romania. All rights reserved

ISSN print: $1224-5984$

ISSN online: $2248-3942$
Rom Biotechnol Lett. 2020; 25(3): 1572-1580

doi: $10.25083 / \mathrm{rbl} / 25.3 / 1572.1580$

Received for publication, November, 3, 2018

Accepted, December, 18, 2018

Original paper

\title{
The Cellular Uptake, Distribution and Toxicity of Poly (lactic-co-glycolic) Acid Nanoparticles in Medicago sativa Suspension Culture
}

\author{
ESMA ULUSOY ${ }^{*}$, SERAP DERMAN², SEMIHA ERISEN ${ }^{1}$
}

${ }^{1}$ Department of Molecular Biology and Genetics, Faculty of Science and Letters, Yildiz Technical University, 34220 Esenler, İstanbul, Turkey

${ }^{2}$ Department of Bioengineering, Faculty of Chemical and Metallurgical Engineering, Yildiz Technical University, 34220 Esenler, İstanbul, Turkey

\begin{abstract}
Nanoparticle systems can be used for agricultural purposes including for risk analysis, application of pesticides or fertilizer, and improving gene transfer technology. Here, the entrance of Fluorescein isothiocyanate isomer I (FITC)-loaded poly (lactic-co-glycolic) acid (PLGA) nanoparticles (NPs) into a Medicago sativa (alfalfa) cell suspension by sonication was studied as a model system for gene transfer in plants. The single emulsion solvent evaporation method was used to synthesis of nanoparticles. Particle size, zeta potential and polydispersity index of nanoparticles were measured and morphological investigation was carried out for nanoparticle characterization. The cytotoxic and genotoxic effects of PLGA NPs were determined on alfalfa cells using 3-(4,5-dimethylthiazol-2-yl)2,5-diphenyltetrazolium bromide (MTT) and comet assay, respectively. Ultrasound application increases the cellular uptake of PLGA NPs. The best result $(82.66 \%)$ was obtained at 3 min of sonication. Transmission Electron Microscopy (TEM) analyses showed that PLGA NPs up to $100 \mathrm{~nm}$ passed through the cell wall and were distributed into the cytoplasm and nucleus. Furthermore, a cytotoxic and genotoxic effect was not observed in the cultured cells exposed to PLGA NPs by sonication. Thus, PLGA NPs system could be used in various agricultural systems in plants. This protocol is an alternative and safe method for gene transfer in plants.
\end{abstract}

Keywords Medicago sativa, nanoparticles, PLGA, suspension cell culture, sonication.

To cite this article: ULUSOY E, DERMAN S, ERISEN S. The Cellular Uptake, Distribution and Toxicity of Poly (lactic-co-glycolic) Acid Nanoparticles in Medicago sativa Suspension Culture. Rom Biotechnol Lett. 2020; 25(3): 1572-1580. DOI: $10.25083 / \mathrm{rbl} / 25.3 / 1572.1580$

$\square$ *Corresponding author: ESMA ULUSOY, Department of Molecular Biology and Genetics, Faculty of Science and Letters, Yildiz Technical University, 34220 Esenler, İstanbul, Turkey

E-mail: eresmet@gmail.com 


\section{Introduction}

Nanobiotechnology provides novel methods and protocols for life science but is largely limited to animal science and medical research including bioimaging (SHARMA \& al [1]), DNA or drug delivery ( LU \& al [2]; ARASOGLU \& al [3]), biosensors (ZARE \& al [4]), etc. Lately, nanoparticle-based explorations have also been used in plant biotechnology. New applications such as pesticide and fertilizer treatments and genetic manipulations with nucleic acids can be improved with nanoparticles (NPs) for agriculture and plant surveys (CIFUENTES \& al [5]). Traditional plant gene transformation methods such as particle bombardment have many limitations - the naked DNA is damaged or destroyed most of the time. In the latest technology fields, studies have verified that nanoparticles can prevent DNA damage and improve transformation (UR REHMAN \& al [6]). Besides, the minimum amount of DNA required for detection of expression was 1000 times lower than that required for Agrobacterium transformation technic in NP-mediated method. It is also able to co-deliver more than one biomolecule concurrently to the target, such as DNA and its activator, DNA and proteins compared with traditional methods (WANG \& al [7]).

Although many studies have been conducted on mammalian systems; due to the presence of plant cell wall composed of cross-linked polysaccharides, the results are difficult to translate to plants (VALLETTA \& al [8]). This cell wall surrounds the cell membrane and inhibits entry of NPs into plant cells. Previously, the cellular uptake of $\mathrm{CdSe} / \mathrm{ZnS}$ quantum dots, polyethylene, and carbon nanomaterials were studied in plant cells with a protoplast, i.e., removing this extra barrier (SERAG \& al [9]; SILVA $\&$ al [10]). Nevertheless, protoplast methods decrease the vitality and proliferation of the protoplasts and might not be representative (XIA \& al [11]). Thus, new studies have evaluated intact plant cells; the internalization of carbon nanotubes and quantum dots from the extracellular environment can be performed via cellular endocytosis (PASUPATHY \& al [12]; DONG \& al [13]) or creating new pores with ultrasound (LIU \& al [14]). However, carbon nanotubes and $\mathrm{CdSe} / \mathrm{ZnS}$ quantum dots are quite toxic in plants (DONG \& al [13]; SANTOS \& al [15]).

To avoid this problem, natural and synthetic polymers can be used in different bio-nanotechnology applications (VARMA \& al [16]). The most well-known and welldefined polymers are polylactic acid (PLA), polyglycolic acid (PGA), and their copolymers of poly(lactic-co-glycolic) acids (PLGA) (SANTO \& al [17]; CHRONOPOULOU \& al [18]). FDA-approved PLGA polymers with biocompatible and biodegradable properties have been used as carriers for many years (VIDAWATI \& al [19]). PLGAbased NPs are one of the most reliable carriers today, but their use in plants is rarely studied. While PLGA NPs are not cytotoxic in animal cells, their cytotoxicity and genotoxicity in plant cells remains unclear. The interaction of PLGA NPs with plants was first described by VALLETTA et al [8]. Here, the phytotoxicity of PLGA
NPs on Vitis vinifera cell lines was investigated, and viability analysis showed that PLGA NPs were not cytotoxic for $V$. vinifera cells. Valletta et al showed that, the PLGA NPs could pass through the plant cell wall and the membrane of $V$. vinifera cell lines and grapevine pathogenic fungi.

Biodegradable NPs play a potential role in agriculture, but the uptake, transport, and aggregation of NPs varies according to plant species (LIN \& XING [20]; LIN \& al [21]). Studies in the literature have shown that NPs entrance also depends on their shape, size, concentration, and mode of administration (WILD \& JONES [22]; HISCHEMŌLLER \& al [23]). Thus, this work describes the following: i) synthesis and characterization of Fluorescein isothiocyanate isomer I (FITC)-loaded PLGA NPs, ii) examination of the effects of ultrasonication on the uptake and distribution of the NPs into alfalfa cells, and iii) evaluation of the cytotoxic and genotoxic effects of PLGA NPs on alfalfa cells.

For the first time, the cellular uptake and distribution of larger $(\sim 100 \mathrm{~nm})$ PLGA NPs via ultrasonication have been demonstrated, and the NPs have not cytotoxic or genotoxic effect on alfalfa cells.

\section{Materials and Methods}

PLGA 50:50, Mw 38.000-54.000 Da, MT) powder, FITC dye, and Triton X-100 were obtained from SigmaAldrich (St. Louis, Missouri). Dimethyl sulfoxide (DMSO) was from Merck Millipore. The low electroendosmosis (EEO) agarose and high EEO agarose was from AppliChem. Murashige \& Skoog (MS) medium, sucrose, agar, and growth regulators were obtained from Duchefa (Netherlands). M. sativa (alfalfa) seeds were provided by Dr. Sat1 Uzun (University of Erciyes, Turkey) using a plant material.

Establishment of suspension culture of alfalfa: The surface sterilization of alfalfa seeds was performed by using $50 \%$ commercial bleach $(5 \% \mathrm{NaOCI})$ for 10 minutes and then rinsing with sterile distilled water three times. After that, they were germinated on MS medium (MURASHIGE \& SKOOG [24]) with $3 \%(\mathrm{w} / \mathrm{v})$ sucrose and $0.8 \%(\mathrm{w} / \mathrm{v})$ agar. The $\mathrm{pH}$ of the medium was adjusted to 5.6 before sterilization at $121^{\circ} \mathrm{C}$ for $25 \mathrm{~min}$. Hypocotyls were removed from 7-day-old aseptic seedling and used as the explant. The explants $(0.5-1.0 \mathrm{~cm})$ were cultured on MS medium with $3 \mathrm{mg} / \mathrm{l} 2.4-\mathrm{D}$ and $0.5 \mathrm{mg} / \mathrm{l} \mathrm{Kin}$ for callusing. After 6 weeks, cell suspension cultures were initiated with $1 \mathrm{gr}$ of friable callus in $50 \mathrm{ml}$ MS liquid medium including the same plant growth regulator composition used for callusing in $150 \mathrm{ml}$ Erlenmeyer flasks. The cultures were shaken continuously at $110 \mathrm{rpm}$ in an orbital shaker. The cultures were kept in the growth chamber at $24 \pm 2^{\circ} \mathrm{C}$ in the dark. After 21 days, $30 \mathrm{ml}$ of fresh media was added to $10 \mathrm{ml}$ of decanted suspension culture. The suspensions were then sub-cultured every 10 days by transferring 10 to $30 \mathrm{ml}$ of fresh medium. The cell density was $\sim 1.5 \times 10^{5}$ cells, and these suspension cultures were used as a stock.

Synthesis and characterization of FITC-loaded PLGA NPs: The synthesis of FITC-loaded PLGA NPs 
was performed using a modified single emulsion solvent evaporation technique (ARASOGLU \& DERMAN [25]) for fluorescence observation of cellular uptake of NPs. Emulsion solvent evaporation is a common method used in the preparation of nanoparticles. Here, $50 \mathrm{mg}$ of PLGA polymer and $3 \mathrm{mg}$ of FITC were dissolved in $2 \mathrm{ml}$ of Dichloromethane (DCM) and added to $4 \mathrm{~mL}$ of $3.0 \%$ Poly (vinyl alcohol) (PVA) solution and sonicated for 2 minutes at $80 \%$ power to obtain uniform emulsions. The nanoparticle solution was then added dropwise to $35 \mathrm{~mL}$ of $0.1 \%$ PVA solution and stirred overnight at $500 \mathrm{rpm}$ using a magnetic stirrer for evaporation of the organic solvent. After removal of the organic solvent, the NPs were precipitated by centrifugation and washed three times with $\mathrm{dH}_{2} \mathrm{O}$. The resulting NPs were dried by lyophilization, and the particle size and zeta potential were measured according to the literature (DERMAN [26]) using a Malvern Zetasizer-Nano ZS.

Scanning electron microscopy (SEM) analysis of nanoparticles: SEM (HITACHI Regulus $8230 \mathrm{FE}$ ) was used for morphological investigation of the NPs. This technique was used by slightly modifying the procedure previously reported by HUSSAIN [27]. The lyophilized NPs were mounted onto an aluminum stub using doublesided carbon tape. The samples were then coated with a 10-nm-thick gold + palladium film using a sputter coater. Coated samples were analyzed at $20 \%$ in resolution at $1 \mathrm{kV}$ landing voltage.

Cell viability: Cell viability was tested at different sonication times. The $1 \mathrm{ml}$ of alfalfa cell $\left(\sim 1.5 \times 10^{5}\right)$ suspensions were transferred to tubes, and the cell culture samples were sonicated during 1, 3, 5, 7 and 9 min and centrifuged at $2000 \mathrm{rpm}$ for $5 \mathrm{~min}$ to collect the cells. The viability of the cell was evaluated using a MTT assay (ABE \& MATSUKI [28]) with minor modifications:100 $\mu$ l of $5 \mathrm{mg} / \mathrm{ml}$ MTT was added to each tube and incubated at $24^{\circ} \mathrm{C}$ for $2 \mathrm{~h}$. in the dark on a shaker. The supernatant was removed by centrifugation at $3000 \mathrm{rpm}$ for $5 \mathrm{~min}$ and resuspended with $200 \mu \mathrm{l}$ of DMSO for $10 \mathrm{~min}$. The supernatant was placed in microplates and then analyzed at $570 \mathrm{~nm}$ on a universal microplate reader (Shimadzu, UV-1800). The cell viability (\%) was calculated as follows: (Sample optical density/control optical density)*100. After the best sonication times were determined, these sonication times were re-tested with PLGA NPs $\left(15 \mathrm{mg} \mathrm{l}^{-1}\right)$ at different incubation times $(0,30$ and $60 \mathrm{~min})$ in the alfalfa cell cultures.

The uptake and localization of PLGA NPs in alfalfa cell culture: FITC-loaded PLGA NPs are directly added to 5-6 days old suspension cell culture medium at a final concentration of $15 \mathrm{mg} \mathrm{l}^{-1}$. The suspension was added to $1 \mathrm{ml}$ tubes. The cultures were sonicated in an ultrasonic bath for 1 or 3 minutes, with $35 \mathrm{kHz}$ frequency and $60-120 \mathrm{~W}$ at $25^{\circ} \mathrm{C}$. After that, the cells were washed three times with MS medium, and the NPs were removed by centrifugation at $2000 \mathrm{rpm}$ for $5 \mathrm{~min}$ to separate the cells from the culture medium. After centrifugation, the supernatant was aspirated and discarded, and the cells were resuspended in MS medium for immediate observation. The cell suspension was placed on slides for visualization of NPs after 0,30 , or $60 \mathrm{~min}$. The intracellular uptake and localization of FITCloaded PLGA NPs (490-525 nm wavelength width) were visualized, and images were collected with a fluorescence microscope. The cellular uptake $(\%)$ was calculated as follows: number of labeled cells/total cell number) $* 100$.

Comet Assay: Comet assay was performed to identify the genotoxic effects of PLGA NPs on alfalfa cells $\left(15 \mathrm{mg} \mathrm{l}^{-1}\right)$ after 3-min ultrasound treatment. The suspended cells were placed in $1 \mathrm{ml}$ tubes and then frozen in liquid nitrogen and crushed in a mortar. Later, 200 microliters of the nucleus suspension were stirred with 200 microliters of low melting agarose (LMA-1\%). Each microscope slide was precoated with a layer of $0.65 \mathrm{~g}$ high melting point agarose (HMA) dissolved in $100 \mathrm{ml}$ of $\mathrm{dH}_{2} \mathrm{O}$ in microwave. Nuclei were then lysed in high salt buffer $(2.5 \mathrm{M} \mathrm{NaCl}, 10 \mathrm{mM}$ Tris-HCl, pH 10, $100 \mathrm{mM}$ EDTA) for $20 \mathrm{~min}$ at room temperature. The electrophoresis buffer $(10 \mathrm{M} \mathrm{NaOH}$, $200 \mathrm{mM}$ EDTA) was attached to a power source of 24 volts $(\sim 0.74 \mathrm{~V} / \mathrm{cm})$ with a current of $300 \mathrm{~mA}$. The slides were run on the electrophoresis system for 30 minutes depending on the degree of migration in the samples. The slides were then slowly removed from the tamping and placed on a discharge tray. The slides were then left in the neutralization buffer $(0.4 \mathrm{M}$ Tris $(48.5 \mathrm{gm}$ added to $\sim 800 \mathrm{~mL}$ $\left.\mathrm{dH}_{2} \mathrm{O}\right)$ adjusted to $\mathrm{pH} 7.5$ with concentrated $\left.(>10 \mathrm{M}) \mathrm{HCl}\right)$. This then incubated for 3 to 5 minutes. At the final stage, the slides were stained with $80 \mu \mathrm{L}$ of $1 \mathrm{X}$ ethidium bromide, allowed to stand for 5 minutes, and then immersed in cooling distilled water to take remove stain (DHAWAN \& al [29]). The samples were covered with a watch glass and used rapidly for observation with a Zeiss Axiovert A1 fluorescence microscope (Zeiss, Germany).

Transmission electron microscopy (TEM): TEM was used to determine the intracellular location and size of the PLGA NPs after sonication. Cells were added to $1 \mathrm{ml}$ tubes, centrifuged (2000 rpm-5 min), and fixed in $3 \%$ glutaraldehyde for $1 \mathrm{~h}$. The supernatant was then discarded, and the cells were washed in $0.1 \mathrm{M}$ sodium phosphate buffer $(\mathrm{pH} 7.4)$ for $10-15 \mathrm{~min}$. The supernatant was discarded, and $0.5 \mathrm{ml}$ of $15 \%$ liquid BSA was added to the samples for $1 \mathrm{hr}$. After, equal volume of glutaraldehyde fixative was added to the BSA and allowed to react for 2-24 h. The samples were removed and divided into small portions. They were then continuously washed twice in $0.1 \mathrm{M}$ sodium phosphate buffer ( $\mathrm{pH}$ 7.4) during the first fixation. The specimens were then washed 3 times and postfixed overnight in $1 \%(\mathrm{w} / \mathrm{v})$ aqueous osmium tetroxide in $0.2 \mathrm{M}$ sodium phosphate buffer (BANCROFT \& al [30]). After these two fixations, the samples were dehydrated by passing the slides through graded ethanol and propylene oxide solutions; the final step is an epoxy resin. Thin sections were sliced with an ultramicrotome (Ultracut, Austria) equipped with a diamond knife, post-stained successively with uranyl acetate and lead citrate and then examined with a TEM (JEOL, JEM-1220, Japan).

Data analysis: Each application contained three replicates and all treatments were repeated twice. The data were studied with analysis of variance (ANOVA) with 
the Duncan's multiple range test set at a 0.05 level of significance. The T-test was used to compare groups.

\section{Results and Discussion}

\section{Characterization of FITC-loaded PLGA NPS}

Here, a single emulsion solvent evaporation method was used to prepare FITC-loaded PLGA NPs. Particle size, zeta potential, and polydispersity index analysis of the NPs were carried out using photon correlation spectroscopy. The particle size distribution graph was shown (Fig. 1A), and the dimensions of synthesized nanoparticles vary between $60-500 \mathrm{~nm}$. The morphological analyses of NPs were carried out using SEM (Fig. 1B). The SEM images showed that the nanoparticles have spherical, smooth morphology, and the size between 40-500 $\mathrm{nm}$. The characteristic properties of NPs are compatible with other studies which used the same method (ANANTA \& al [31]; ROY \& al [32]).
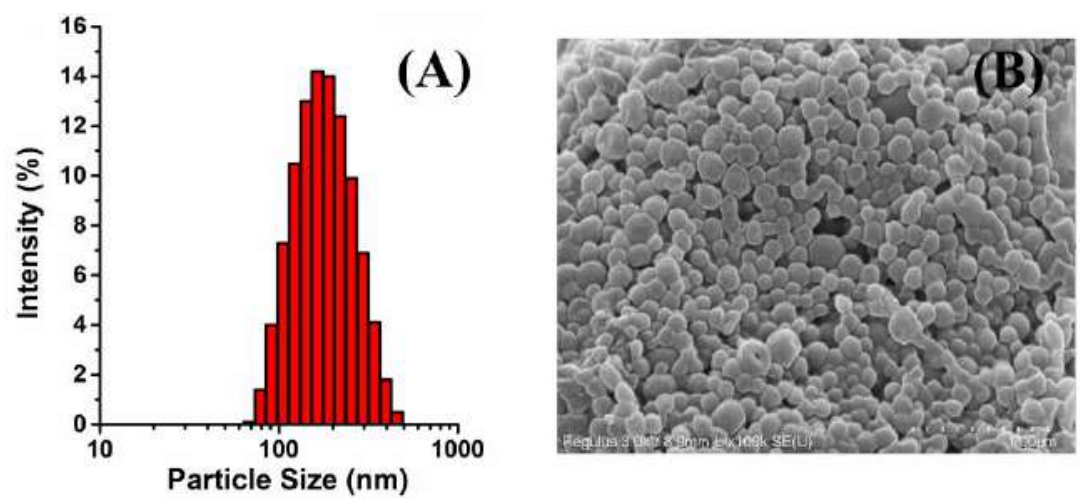

Figure 1. Particle size distribution (A) and SEM image of FITC loaded PLGA nanoparticles (B).

\section{Cell viability}

The low levels of sonication can lead to various mechanical and biological effects on the plant cells, and this can be applied to plant biotechnology (LIU \& al [14]). Therefore, in the first part of the study the effect of different sonication times $(1,3,5,7$, and 9 min) on cell viability were monitored (Fig. 2). The results showed that the effect of sonication time leads to significant differences $(p<0.01)$. The 1 and 3 min sonication treatments had similar effects on the alfalfa cell culture, the cell viabilities were $92.05 \%$ and $89.80 \%$, respectively. However, the cell viabilities were dramatically decreased with longer time treatments for 5,7 , and 9 min led to $46.80 \%, 33.80 \%$ and $25.71 \%$ viability, respectively. Based on the results, the optimal sonication times were determined to be $1 \mathrm{~min}$ and $3 \mathrm{~min}$.

Prior studies showed that $90 \%$ of cells were damaged when treated with sonication for 7 to 11 minutes (LIU \& al [14]) or up to $20 \mathrm{~min}$ (AMANI \& al [33]). It was observed that the cell viability dramatically decreased when more than 3 min of sonication was used. Cell damage was detected on $\sim 70 \%$ for 7 to 9 min sonication treatment. The results indicated that 1 to $3 \mathrm{~min}$ of sonication could facilitate NP labeling with low background cell damage.

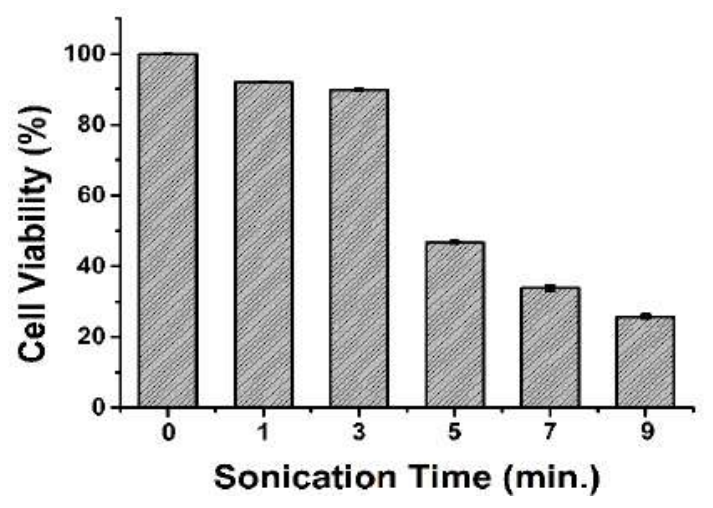

Figure 2. The effect of sonication times on cell viability.

In the second part of the study, the effects of different incubation times with PLGA NPs, on cell viability were investigated for 1 and 3 min sonication treatment. After the incubation of cells with PLGA NPs for 0, 30 and $60 \mathrm{~min}$, the cell viability was determined as $106.79 \%, 89.07 \%$, $76.57 \%$, respectively at $1 \mathrm{~min}$ sonication. Additionally, the cell viability for 0,30 , and $60 \mathrm{~min}$ incubation was measured as $80.21 \%, 82.28 \%$, and $86.41 \%$, respectively, at 3 min of 
sonication (Fig. 3). However, no statistically significant difference was observed between different incubation times. Furthermore, no toxic effects were observed in cells incubated with PLGA NPs during different incubation times. The resulting data showed that the PLGA NPs $\left(15 \mathrm{mg} \mathrm{l}^{-1}\right)$ were not cytotoxic on alfalfa cell cultures under these conditions. Similarly, PLGA NPs were not cytotoxic for $V$. vinifera cells (VALLETTA \& al [8]).

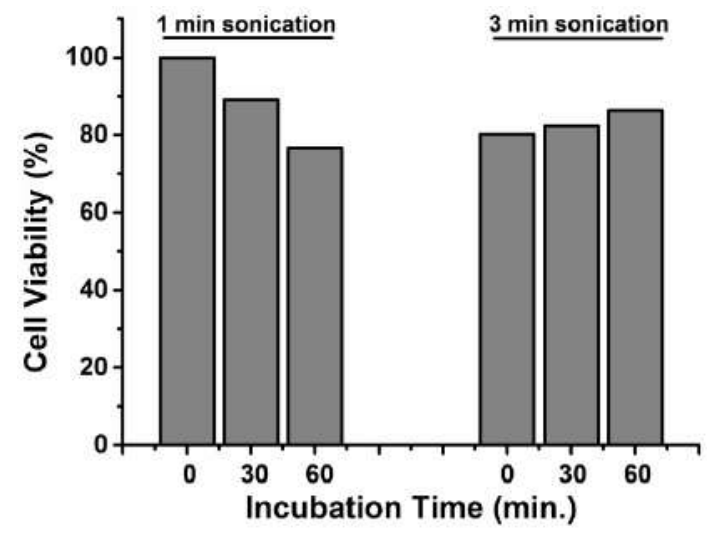

Figure 3. The effect of the PLGA NPs and incubation times on cell viability.

\section{The cellular uptake of PLGA NPs in alfalfa cell culture}

The uptake and distribution of PLGA NPs in alfalfa cells depend on the sonication ( 1 and $3 \mathrm{~min}$ ) and incubation time $(0,30$ and $60 \mathrm{~min})$ was studied. To observe the cellular entry of PLGA NPs, alfalfa cell culture suspensions were incubated with the FITC-loaded PLGA NPs. These NPs were first sonicated at different times in the cell suspension. The non-sonicated alfalfa cells showed no fluorescence, but those with 1 or 3 min of sonication were fluorescent.
The time-dependent entry of FITC-loaded PLGA NPs into alfalfa cell suspensions at 1 and 3 minutes were visualized with fluorescence microscopy (Fig. 4). The PLGA NPs were immediately uptaken by the cells. After the procedure (10-15 minutes), highly fluorescent round bodies with a low diffuse background were visualized in the cells. At longer time points (30-60 $\mathrm{min})$, these fluorescent round bodies became clearer and larger. Fluorescence dispersion was observed at 24 hours similar to the 60-minute PLGA NPs; the subcellular localization was also similar.
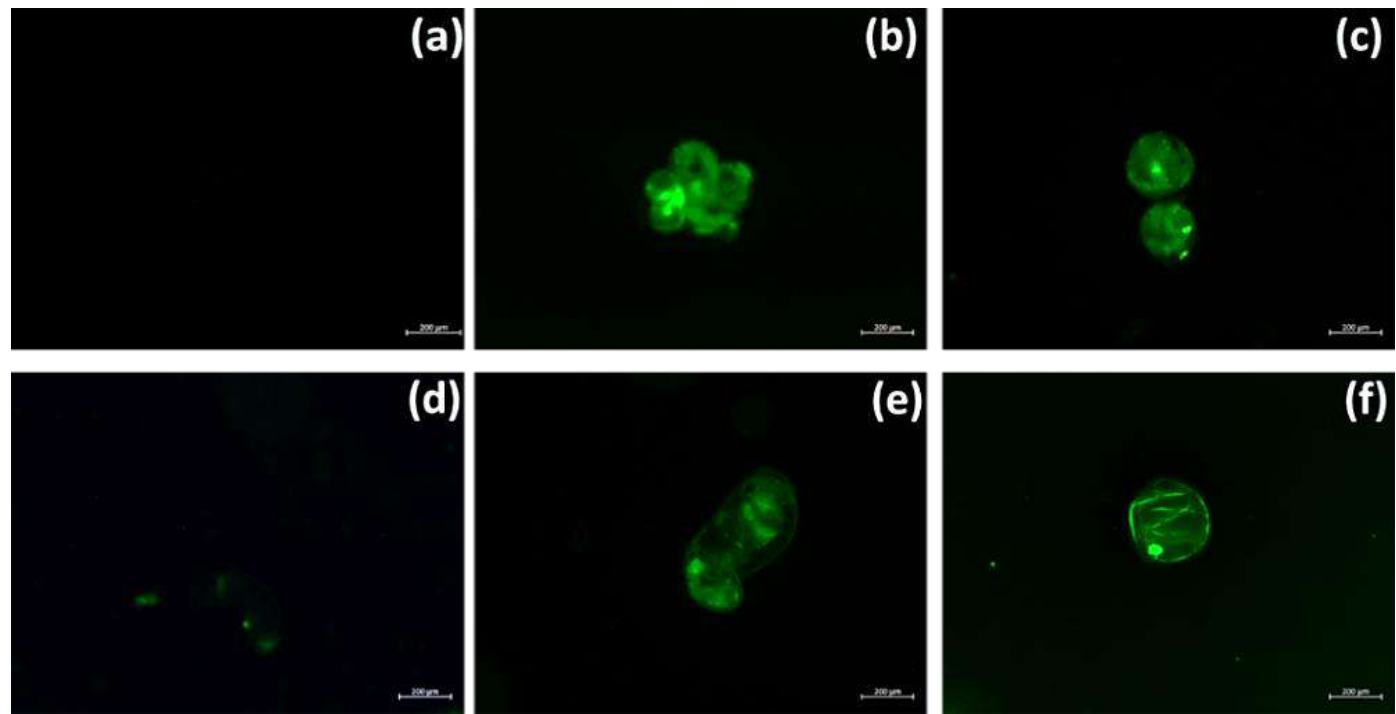

Figure 4. Time-dependent uptake of FITC-loaded PLGA NPs by alfalfa suspensions cultured cells at 1 and 3 minutes in inverted microscopy. At $1 \mathrm{~min}$ of sonication: a) after $0 \mathrm{~min}$; b) $30 \mathrm{~min}$; c) $60 \mathrm{~min}$. At $3 \mathrm{~min}$ sonication: d) after $0 \mathrm{~min}$; e) $30 \mathrm{~min}$; f) $60 \mathrm{~min}$. Scale bars represent $200 \mu \mathrm{m}$.

The cellular uptake (\%) was calculated as a function of sonication and incubation time. The significant differences were observed between $1(1.59 \%)$ and $3 \mathrm{~min}$
$(16.83 \%)$ of sonication at no incubation. At $30 \mathrm{~min}$ of incubation time, the NPs entry was calculated as $73.15 \%$ and $77.73 \%$, respectively for $1 \mathrm{~min}$ and $3 \mathrm{~min}$ ultrasound 
treatment. The cells with 60 min of incubation have $71.9 \%$ labeling at $1 \mathrm{~min}$ and $82.7 \%$ at $3 \mathrm{~min}$ sonication (Fig. 5).
The results showed that the ultrasound treatment improved the cellular uptake efficiency of PLGA NPs by alfalfa cells.

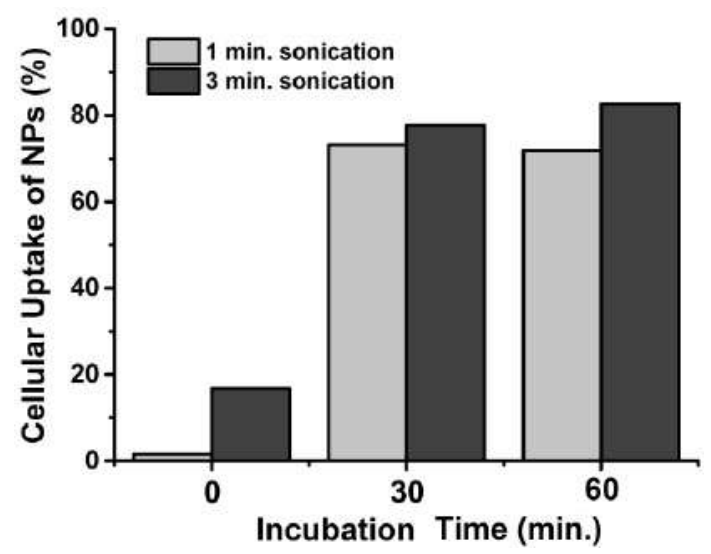

Figure 5. The effect of sonication and incubation time on cellular uptake of FITC loaded PLGA NPs.

The uptake of PLGA NPs into cells and their subcellular dispersion were first visualized by an inverted microscope and then analyzed in detail with TEM. The observations showed that the NPs entered and passed through the cell wall and membrane. They then dispersed in the inner cell and were mainly in the cytoplasm
(Fig. 6 a-e). The PLGA NPs were rarely observed in the nucleus and nucleolus (Fig. 6 a, e). Whereas, the NPs were not seen in the extracellular area of the cells (Fig. 6 b). This is thought to be due to the excessive rinses carried out during fixation and embedding. It is remarkable that the cellular uptake of 45-95 nm NPs was so obvious (Fig. $6 \mathrm{c}, \mathrm{d}$ ).
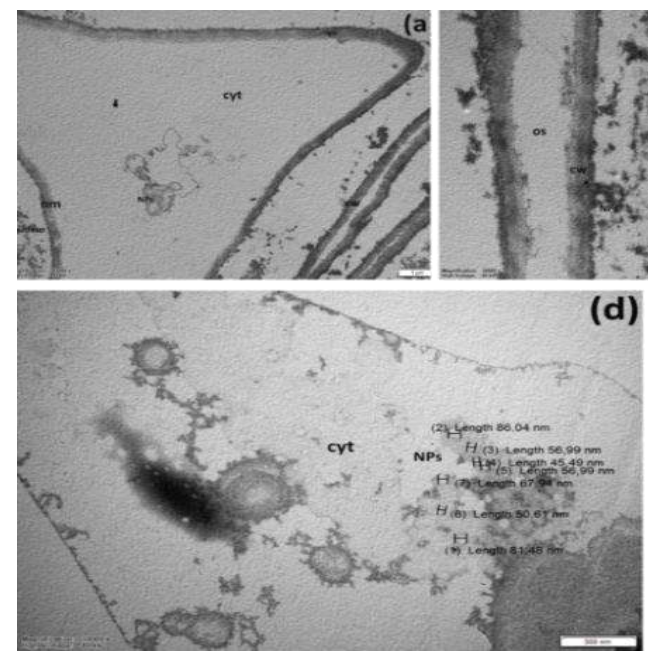
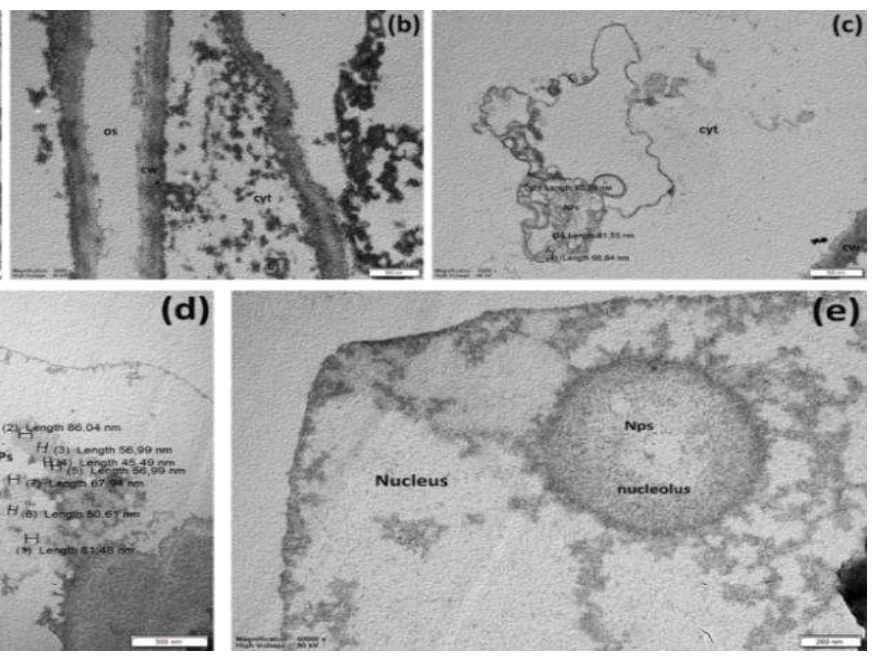

Figure 6. TEM images of the uptake and cellular distribution of PLGA NPs. a) NPs pass through the cell wall (cw) and membrane; b) PLGA NPs were not detectable in the outer space (os) cell wall and membrane; c) and d) The NPs mainly accumulated in the cytoplasm (cyt); e) A few NPs were detected in nucleus and nucleolus.

PLGA NPs are widely used as potential nano-carriers for various molecules such as nucleic acids, peptides, proteins (SAMANI \& TAGHIPOUR [34]). In contrast to metallic nanoparticles, the interaction between polymeric NPs and plants has not been adequately studied. There are only a few studies about cellular uptake of PLGA NPs into plant cells and the studies have been conducted with only $V$. vinifera (VALLETTA \& al [8]; PALOCCI \& al [35]). Plant species are one of the factors that affect the penetration of NPs into cells. Here, the uptake and localization of PLGA NPs into alfalfa cells was demonstrated for the first time. Also, the effect of sonication on the entrance of NPs into cells was determined.

The ultrasound treatment improved the cellular uptake efficiency of the FITC-loaded PLGA NPs into alfalfa cells. The results showed that, cellular uptake of PLGA NPs increases with time and $3 \mathrm{~min}$ of sonication treatment was more effective than $1 \mathrm{~min}$ of sonication. Fluorescence and TEM datas suggested that the NPs were mainly in the cytoplasm with minor uptake in the nucleus 
in cultured alfalfa cells. At 3-5 min of $120 \mathrm{~W} 40 \mathrm{kHz}$ ultrasound, LIU \& al [14] showed that plant cells maintain their normal shape and that NPs are present not only in the cytoplasm but also in the nucleus. In another study, 0.5 to 3 min of ultrasonund treatment could increase the efficiency of gene delivery in alfalfa cells using polyamidoamine (PAMAM) NPs (AMANI \& al [33]). The results indicated that NPs could pass through the cell walls, plasma membranes, and nuclear membranes via ultrasound.

The presence of the cell wall is an obstacle for the NPs uptake by plant cells. It is a barrier that blocks the uptake of NPs larger than the cell wall pores. The literature reports that the largest cell wall pores are 5-20 nm in diameter (NAIR \& al [36]; RICO \& al [37]). VALLETTA $\&$ al [8] showed that only PLGA NPs smaller than 30-50 nm can cross into grape cells. In this study, ultrasound treatment was used differently VALLETTA \& al [8] and TEM analyzes were showed that PLGA NPs up to $100 \mathrm{~nm}$ in diameter could penetrate alfalfa cells. The penetration of larger size NPs could be explained by the use of sonication because of ultrasonic energy can form channels in the cell wall, cell membrane, and nuclear membrane (DENG \& al [38]). In addition, the size of NPs that can penetrate the cells varies depending on the plant species, cell type, and cell growth phases (LIN \& XING [20]; LIN \& al [21]; HISCHEMŌLLER \& al [23]).

\section{Genotoxic potential of PLGA NPs on alfalfa cells}

The comet assay is a very delicate tool for detecting DNA breakage in single cells. Cell cultures supplemented with $15 \mathrm{mg} \mathrm{l}^{-1}$ PLGA NPs were sonicated for $3 \mathrm{~min}$, and the nuclei were then examined via the comet procedure. DNA strand breaks (comets) were not induced in cells exposed to PLGA NPs for $1 \mathrm{~h}$ compared to the level of damage in control cells on microscope images ( 100 nuclei) as shown in Fig. 7. The results shown that PLGA NPs did not have genotoxicity on alfalfa cells.
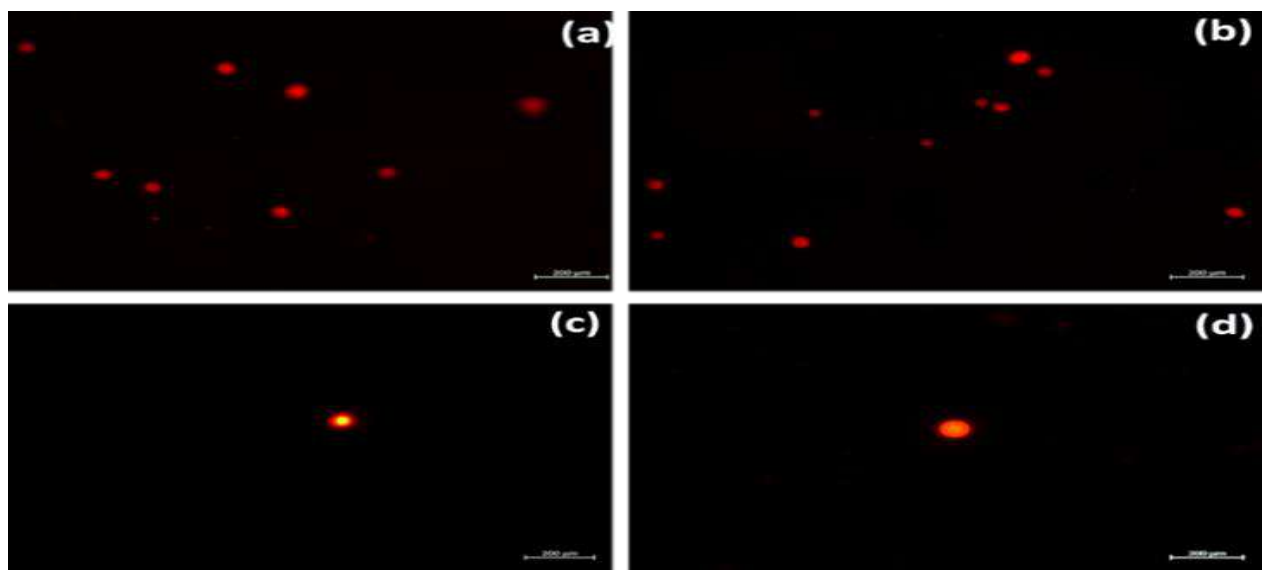

Figure 7. Fluorescence microscopy image of alfalfa cells exposed FITC-loaded PLGA NPs for 3 min of sonication. Scale bars represent $200 \mu \mathrm{m}$.

The remarkable increase in the use of NPs requires careful study of their toxicological effects. The comet assay is frequently used to measure genotoxicity. Toxicological studies with NPs are usually done in animal models and cell lines but rarely in plants (MORENO-OLIVAS \& al [39]). The genotoxic potential of metal NPs such as Ag-NPs (in Allium cepa and Vicia faba), ZnO-NPs and CeO2-NPs (in Glycine max), and TiO2-NPs (in Allium cepa, Nicotiana tabacum, Zea mays and Vicia narbonensis) on plants have been reviewed by CHICHIRICCÒ \& POMA [40]. However, despite the increasing use of polymeric NPs in other areas, there are very few studies on genotoxic potentials in plants. SANTOS \& al [15] demonstrated that $\mathrm{CdSe} / \mathrm{ZnS}$ quantum dots damaged DNA in M. sativa. PLGA can be safely used in drug delivery systems in animals and is not cytotoxic or genotoxic to mammalian cells (SETYAWATI \& al [41]). Here, the genotoxic potential of PLGA NPs in plant cells were also shown for the first time. The results showed that there was no genotoxic potential of the PLGA NPs on alfalfa cells.

\section{Conclusion}

The increasing use of nanobiotechnological products requires careful characterization including studies of the impact of NPs systems on plants and agricultural products. NPs diameter is one of the important factors affecting cellular uptake. The particle size increases when the biomolecule is encapsulated by nanoparticle. To solve this problem, smaller size NPs could be synthesized, or different methods could be developed for cellular uptake of large size NPs. Here, it has been found that the internalization of PLGA NPs in alfalfa cells increases with the use of ultrasound. In addition, it was showed for the first time that PLGA NPs up to $100 \mathrm{~nm}$ in size were penetrate the plant cells after ultrasound treatment. The PLGA NPs do not have any cytotoxic or genotoxic effects on alfalfa cells. Increasing the entrance potential of PLGA NPs to plant cells via ultrasonication will allow biomolecules such as DNA/RNA to be easily transferred to plant cells 
in the future. This might be a safe alternative method for plant gene transfer.

\section{Acknowledgements}

This research has been supported by Y1ldı Technical University Scientific Research Projects Coordination Department, Project number: FDK-2018-3237.

\section{References}

1. P. SHARMA, S. BROWN, G. WALTER, S. SANTRA, B. MOUDGIL, Nanoparticles For Bioimaging. $A d v$. Colloid Interface Sci., 123: 471-485 (2006).

2. H. LU, Y. DAI, L. LV, H. ZHAO, Chitosan-GraftPolyethylenimine/DNA Nanoparticles as Novel NonViral Gene Delivery Vectors Targeting Osteoarthritis. PLoS One, 9(1): (2014).

3. T. ARASOGLU, S. DERMAN, B. MANSUROGLU. Comparative evaluation of antibacterial activity of caffeic acid phenethyl ester and PLGA nanoparticle formulation by different methods. Nanotechnology, 27(2):025103 (2015).

4. H. ZARE, G. D. NAJAFPOUR, M. JAHANSHAHI, M. RAHIMNEJAD, M. REZVANI. Highly stable biosensor based on glucose oxidase immobilized in chitosan film for diagnosis of diabetes. Rom. Biotechnol. Lett., 22:3 (2017).

5. Z. CIFUENTES, L. CUSTARDOY, J.M. DE LA FUENTE, C. MARQUINA, M.R. IBARRA, D. RUBIALES, A. PÉREZ-DE-LUQUE. Absorption and translocation to the aerial part of magnetic carboncoated nanoparticles through the root of different crop plants. J. Nanobiotechnol. 8: 26 (2010).

6. Z.U. REHMAN, I.S. ZUHORN, D. HOEKSTRA. How cationic lipids transfer nucleic acids into cell sand across cellular membranes: recent advances. J. Controlled Release, 166: 46-56 (2013).

7. P. WANG, E. LOMBI, F.-J. ZHAO, P.M. KOPITTKE. Nanotechnology: a new opportunity in plant sciences. Trends Plant Sci., 21: 699-712 (2016).

8. A. VALLETTA, L. CHRONOPOULOU, C. PALOCCI, B. BALDAN, L. DONATI, G. PASQUA. Poly (lacticco-glycolic) acid nanoparticles uptake by Vitis vinifera and grapevine-pathogenic fungi. J. Nanopart. Res., 16: 2744 (2014).

9. A.T. SILVA, A. NGUYEN, C. YE, J. VERCHOT, J.H. MOON. Conjugated polymer nanoparticles for effective siRNA delivery to tobacco BY-2 protoplasts. $B M C$ Plant Biol., 10: 291 (2010).

10. M.F. SERAG, N. KAJI, C. GAILLARD, Y. OKAMOTO, K. TERASAKA, M. JABASINI, M. TOKESHI, H. MIZUKAMI, A. BIANCO, Y. BABA. Trafficking and subcellular localization of multiwalled carbon nanotubes in plant cells. ACS nano, 5: 493-499 (2010).

11. B. XIA, C. DONG, W. ZHANG, Y. LU, J. CHEN, J. SHI. Highly efficient uptake of ultrafine mesoporous silica nanoparticles with excellent biocompatibility by
Liriodendron hybrid suspension cells. Sci. China: Life Sci., 56: 82-89 (2013).

12. K. PASUPATHY, S. LIN, Q. HU, H. LUO, P.C. KE. Direct plant gene delivery with a poly (amidoamine) dendrimer. Biotechnol. J., 3: 1078-1082 (2008).

13. C. DONG, J. SHI, Y. LU, J. CHEN, B. XIA. Interaction characteristics of the co-incubation between $\mathrm{CdSe} / \mathrm{ZnS}$ quantum dots and Liriodendron hybrids suspension cells by PEG-mediation. Scientia Sinica Vitae, 41: 494-501 (2011).

14. J. LIU, F.-H. WANG, L.-L. WANG, S.-Y. XIAO, C.-Y. TONG, D.-Y. TANG, X.-M. LIU. Preparation of fluorescence starch-nanoparticle and its application as plant transgenic vehicle. J. Cent. South Univ. Technol., 15: 768-773 (2008).

15. A.R. SANTOS, A.S. MIGUEL, A. MACOVEI, C. MAYCOCK, A. BALESTRAZZI, A. OLIVA, P. FEVEREIRO. CdSe/ZnS Quantum Dots trigger DNA repair and antioxidant enzyme systems in Medicago sativa cells in suspension culture. BMC Biotechnology, 13: 111 (2013).

16. M.V. VARMA, A.M. KAUSHAL, A. GARG, S. GARG. Factors affecting mechanism and kinetics of drug release from matrix based oral controlled drug delivery systems. Am. J. Drug Delivery 2: 43-57 (2004).

17. V.E. SANTO, A.R.C. DUARTE, M.E. GOMES, J.F. MANO, R.L. REIS. Hybrid 3D structure of poly (d, 1-lactic acid) loaded with chitosan/chondroitin sulfate nanoparticles to be used as carriers for biomacromolecules in tissue engineering. J. Supercrit. Fluids, 54: 320-327 (2010).

18. L. CHRONOPOULOU, A. CUTONILLI, C. CAMETTI, M. DENTINI, C. PALOCCI. PLGA-based nanoparticles: effect of chitosan in the aggregate stabilization. A dielectric relaxation spectroscopy study. Colloids Surf., B., 97: 117-123 (2012).

19. S. VIDAWATI, S. BARBOSA, P. TABOADA, E. VILLAR, A. TOPETE, V. MOSQUERA. Study of Human Serum Albumin-SPIONs Loaded PLGA Nanoparticles for Protein Delivery. Adv. Biol. Chem., 8: 91-100 (2018).

20. D. LIN, B. XING. Root uptake and phytotoxicity of ZnO nanoparticles. Environ. Sci. Technol. 42:55805585 (2008).

21. S. LIN, J. REPPERT, Q. HU, J.S.HUDSON, M.L REID, T.A.RATNIKOVA, A.M.RAO, H. LUO, P.C. KE. Uptake translocation and transmission of carbon nanomaterials in rice. Small, 5: 1128-1132 (2009).

22. E. WILD, K.C. JONES. Novel method for the direct visualization of in vivo nanomaterials and chemical interactions in plants. Environ. Sci. Technol., 43: 52905294 (2009).

23. A. HISCHEMŌLLER, J. NORDMANN, P. PTACEK, K. MUMMENHOFF, M. HAASE. In-vivo imaging of the uptake of up conversion nanoparticles by plant roots. J. Biomed. Nanotechnol., 5:278-284 (2009). 
24. T. MURASHIGE, F. SKOOG. A revised medium for rapid growth and bio assays with tobacco tissue cultures. Physiol. Plant., 15: 473-497 (1962).

25. T. ARASOGLU, S. DERMAN. Assessment of the antigenotoxic activity of poly (d, 1-lactic-co-glycolic acid) nanoparticles loaded with caffeic acid phenethyl ester using the AMES/Salmonella microsome assay. J. Agric. Food Chem., 66 (24): 6196-6204 (2018).

26. S. DERMAN. Caffeic acid phenethyl ester loaded PLGA nanoparticles: effect of various process parameters on reaction yield, encapsulation efficiency, and particle size. J. Nanomater., 16: 318 (2015).

27. H.I. HUSSAIN, Z. YI, J.E. ROOKES, L.X. KONG, D.M. CAHILL. Mesoporous silica nanoparticles as a biomolecule delivery vehicle in plants. J. Nanopart. Res., 15: 1676 (2013).

28. K. ABE, N. MATSUKI. Measurement of cellular MTT reduction activity and lactate dehydrogenase release using MTT. Neurosci. Res. (Shannon, Irel.), 38: 325329 (2000).

29. A. DHAWAN, M.M. BAJPAYEE, A.K. PANDEY, D. PARMAR. Protocol for the single cell gel electrophoresis/comet assay for rapid genotoxicity assessment. Sigma, 1077 (2003).

30. J.D. BANCROFT, A.D. FLOYD, S.K. SUVARNA. Bancroft's Theory and Practice of Histological Techniques. Churchill Livingstone $7^{\text {th }}$ (edn), Nottingham. pp. 500-502 (2013).

31. J.S. ANANTA, R. PAULMURUGAN, T.F. MASSOUD. Temozolomide-loaded PLGA nanoparticles to treat glioblastoma cells: a biophysical and cell culture evaluation. Neurol. Res., 38(1): 51-59 (2016).

32. M. ROY, R. PAL, A.S. CHAKRABORTI. Pelargonidin-PLGA nanoparticles: Fabrication, characterization, and their effect on streptozotocin induced diabetic rats. Indian J. Exp. Biol., 55: 819-830 (2017).

33. A. AMANI, N. ZARE, A. ASADI, R.A. ZAKARIA. Ultrasound-enhanced gene delivery to alfalfa cells by hPAMAM dendrimer nanoparticles. Turk. J. Biol., 42: 63-75 (2018).
34. S.M. SAMANI \& B. TAGHIPOUR. PLGA micro and nanoparticles in delivery of peptides and proteins; problems and approaches. Pharm. Dev. Technol., 20(4): 385-393 (2015).

35. C. PAlOCCI, A. VAlletta, L. CHRONOPOULOU, L. DONATI, M. BRAMOSANTI, E. BRASILI, B. BALDAN, G. PASQUA. Endocytic pathways involved in PLGA nanoparticle uptake by grapevine cells and role of cell wall and membrane in size selection. Plant Cell Rep., 36: 1917-1928 (2017).

36. R. NAIR, S.H. VARGHESE, B.G. NAIR, T. MAEKAWA, Y. YOSHIDA, D.S. KUMAR. Nanoparticulate material delivery to plants. Plant Sci. (Shannon, Irel.), 179, 154163 (2010).

37. C.M. RICO, S. MAJUMDAR, M. DUARTEGARDEA, J.R. PERALTA-VIDEA, J.L. GARDEATORRESDEY. Interaction of nanoparticles with edible plants and their possible implications in the food chain. J. Agric. Food Chem., 59: 3485-3498 (2011).

38. C.X. DENG, F. SIELING, H. PAN, J. CUI. Ultrasound-induced cell membrane porosity. Ultrasound in Med. \& Biol., 30: 519-526 (2004).

39. F. MORENO-OLIVAS, V.U. GANT, K.L. JOHNSON, J.R. PERALTA-VIDEA, J.L. GARDEATORRESDEY. Random amplified polymorphic DNA reveals that $\mathrm{TiO} 2$ nanoparticles are genotoxic to Cucurbita pepo. J. Zhejiang Univ., Sci., A 15: 618-623 (2014).

40. G. CHICHIRICCÒ, A. POMA. Penetration and toxicity of nanomaterials in higher plants. Nanomaterials, 5: 851-873 (2015).

41. M.I. SETYAWATI, P.K.S. KHOO, B.H. ENG, S. XIONG, X. ZHAO, G.K. DAS, T.T.Y. TAN, J.S.C. LOO, D.T. LEONG, K.W. Cytotoxic and genotoxic characterization of titanium dioxide, gadolinium oxide, and poly (lactic-co-glycolic acid) nanoparticles in human fibroblasts. J. Biomed. Mater. Res., Part A 101: 633-640 (2013). 